\title{
Hypothalamic-pituitary-ovarian Axis in Thyroid Dysfunction
}

\author{
AF Ajayi ${ }^{1}$, RE Akhigbe ${ }^{1}$, LO Ajayi ${ }^{2}$
}

\begin{abstract}
Background: It has been established that thyroid dysfunction causes impairment of reproductive function. However, laboratory and human studies that associated this with female reproductive hormones are conflicting and data reporting the effects of thyroid dysfunction on reproductive organs are insufficient.

Aim: This study investigated the effect of experimental hypothyroidism and hyperthyroidism on hypothalamic-pituitary-ovarian axis and reproductive organs morphometry and histology in female rats.

Methods: Laboratory animals were randomized into one of the three groups: control, carbimazoleinduced hypothyroidism and levothyroxine-induced hyperthyroidism.

Results: Organ morphometry and serum follicle stimulating hormone (FSH) were statistically comparable across all groups. Serum progesterone increased in hypothyroid rats but was reduced in hyperthyroid rats when compared with the control $(\mathrm{p}<0.05)$. Body weight gain, serum luteinizing hormone and oestradiol were significantly reduced in both hypothyroid and hyperthyroid states when compared to the control. Hypothyroidism and hyperthyroidism also led to alterations in organ cytoarchitecture.

Conclusion: Findings from this study suggest that impairment of reproductive function associated with thyroid dysfunction is attendant with derangement of hormonal milieu and alteration in reproductive organs cytoarchitecture. Luteinizing hormone and oestradiol are implicated.
\end{abstract}

Keywords: Fertility, follicle stimulating hormone, hyperthyroidism, hypothyroidism, luteinizing hormone, oestradiol, progesterone

\section{EI Eje Hipotalámico-pituitario-ovárico en la Disfunción Tiroidea}

\author{
AF Ajayi, RE Akhigbe, LO Ajayi
}

\begin{abstract}
RESUMEN
Antecedentes: Se ha establecido que la disfunción de la tiroides causa deterioro de la función reproductiva. Sin embargo, los estudios humanos y de laboratorio que asociaban tal disfunción a las hormonas reproductoras femeninas son contradictorios, y los datos que reportan los efectos de la disfunción tiroidea sobre los órganos reproductores son insuficientes.

Objetivo: Este estudio investigó el efecto del hipotiroidismo y el hipertiroidismo experimentales sobre el eje hipotalámico-pituitario-ovárico, y la morfometría e histología de los órganos reproductores en ratas hembras.

Métodos: Los animales de laboratorio fueron asignados al azar a uno de estos tres grupos: control, hipotiroidismo inducido por carbimazol, e hipertiroidismo inducido por levotiroxina.

Resultados: La morfometría de los órganos y hormona folículo-estimulante (FSH) en suero, fueron estadísticamente comparables en todos los grupos. La progesterona sérica aumentó en las ratas hipotiroideas, pero se redujo en las ratas hipertiroideas en comparación con el grupo de control $(\mathrm{p}<$ 0.05). El aumento de peso corporal, la hormona luteinizante en suero, y el estradiol se redujeron significativamente tanto en condiciones de hipotiroidismo como en estado de hipertiroidismo, en
\end{abstract}

From: ${ }^{1}$ Department of Physiology and ${ }^{2}$ Department of Biochemistry, Faculty of Basic Medical Sciences, College of Health Sciences, Ladoke Akintola University of Technology, Ogbomoso, Oyo state, Nigeria.
Correspondence: RE Akhigbe, Department of Physiology, Faculty of Basic Medical Sciences, College of Health Sciences, Ladoke Akintola University of Technology, Ogbomoso, Oyo state, Nigeria. E-mail: akhigberoland@ gmail.com 
comparación con el grupo control. El hipotiroidismo y el hipertiroidismo condujeron también a alteraciones en la citoarquitectura de los órganos.

Conclusión: Resultados de este estudio sugieren que la debilitación de la función reproductora asociada con la disfunción de la tiroides, va acompañada de trastornos del medio hormonal, e implica alteraciones de la citoarquitectura de los órganos reproductores, la hormona luteinizante, y el estradiol.

Palabras claves: Fertilidad, folículo estimulante hormonal, hipertiroidismo, hipotiroidismo, hormona luteinizante, estradiol, progesterona

West Indian Med J 2013; 62 (9): 836

\section{INTRODUCTION}

Procreation is a basic phenomenon necessary to sustain life. It involves events regulated by the hypothalamic-pituitarygonadal axis. This axis affects the hormonal environment of the female reproductive system, which thus influences menstrual pattern and fecundity. Alteration of the female reproductive hormones from their normal ranges optimal to achieve proper reproductive functions may lead to infertility, the inability to naturally conceive and carry pregnancy to term despite regular unprotected sexual intercourse for a year $(1,2)$. Infertility is a complex disorder with significant medical, psychosocial and economic problems (3). Documented data revealed that $10-15 \%$ of couples in the world experience infertility (4). This is higher in Sub-Sahara Africa where $20-60 \%$ was reported (5). In Nigeria, $20-50 \%$ of the causes of infertility are due to male factors while $50-80 \%$ are due to female and unexplained factors (6). Risk factors for infertility include, but may not be limited to, thyroid disease, weight changes, hormonal imbalance, environmental factors (such as chemical dust, pesticides), age, lifestyle, pathologies and structural obstruction in the reproductive structures/ organs, pelvic inflammatory disease, sexually transmitted disease and chemotherapy (3).

Thyroid dysfunction interferes with the physiology of reproduction. Women are at higher risk of thyroid diseases (7). The prevalence of abnormal thyroid-stimulating hormone (TSH) level in infertile married women was reported as $6.3 \%, 4.8 \%, 2.6 \%$ and $1.5 \%$ for those diagnosed with anovulatory infertility, unexplained infertility, tubal infertility and male infertility, respectively (8). Hyperthyroidism is associated with infrequent and scanty menses, and amenorrhoea, while hypothyroidism is associated with too frequent and heavy menses (due to reduced levels of clotting factors VII, VIII, IX and XI), diminished libido and anovulation. Both hyperthyroidism and hypothyroidism have significant effects on oestrogen and androgen metabolism (9-11). Thyroid dysfunction upsets the body's reproductive hormones, thus halting ovulation; this could also shorten the luteal phase and lead to loss of early pregnancies (7).

The present study was carried out to systematically document the effects of thyroid dysfunction, hypothyroidism and hyperthyroidism, on female reproductive hormones, as an index of hypothalamic-pituitary-ovarian axis function. It also reports the effect of thyroid dysfunction on reproductive organ morphology and histomorphology.

\section{SUBJECTS AND METHODS \\ Animals}

Female Sprague Dawley rats of comparable weight (151.2 \pm $3.4 \mathrm{~g}$ ) were obtained from the Animal Holding Unit of the Department of Physiology, Ladoke Akintola University of Technology, Ogbomoso, Nigeria. The animals were kept in wire mesh cages and were acclimatized to laboratory condition (12 dark:12 light cycle). They were allowed unrestricted access to rat pellet and water.

\section{Treatments}

Rats were randomly allocated into three groups $(n=6)$ : control, hypothyroid and hyperthyroid. Thyroid dysfunction was induced as described in our previous study (12). Hypothyroidism was induced by administration of $5 \mathrm{mg} / 250 \mathrm{~g}$ body weight of carbimazole, while hyperthyroidism was induced by administration of $5 \mu \mathrm{g} / 100 \mathrm{~g}$ body weight of levothyroxine. Treatments lasted for 35 days. Experimental study was in accordance with the institution's guidelines and that of the European convention for the protection of vertebrate animals and other scientific purposes - ETS-123 (13).

\section{Determination of body weight gain, organ morphometry, and female reproductive hormones}

The weights of rats were recorded weekly (14), and at the end of the experiment, the body weight gain of each rat was determined as the difference between the final and initial body weights. At the end of the experiment, blood samples were collected by cardiac puncture under ether anaesthesia. Serum was obtained and serum luteinizing hormone (LH), follicle stimulating hormone (FSH), oestradiol, and progesterone were assayed. The ovaries, oviducts and uterus of rats were excised, blotted with tissue paper and thereafter weighed. The length and diameter of the excised organs were also measured. Serum LH, FSH, oestradiol and progesterone were assayed using standard assay kit (15). Histomorphologic studies were done as previously described $(16,17)$. Tissue processing was carried out by autotechnicon. Several $5 \mu \mathrm{m}$ thick sections were prepared and mounted on slides and stained with haematoxylin and eosin (H\&E). Stained sec- 
tions were morphologically evaluated and the microphotograph was taken.

\section{Statistical analysis}

Data were analysed using one-way analysis of variance (ANOVA) complemented with unpaired $t$-test. Duncan multiple range test and Turkey's multiple comparison test were used as post-hoc tests. Data are expressed as mean \pm standard deviation.

\section{RESULTS}

Experimental hypothyroidism and hyperthyroidism led to significant reductions in body weight gain when compared to the control. The reduced weight gain observed in hypothyroidism was significantly higher than that in hyperthyroidism [Fig. 1]. Figure 2 shows that reproductive organs morphometry was comparable across all groups.

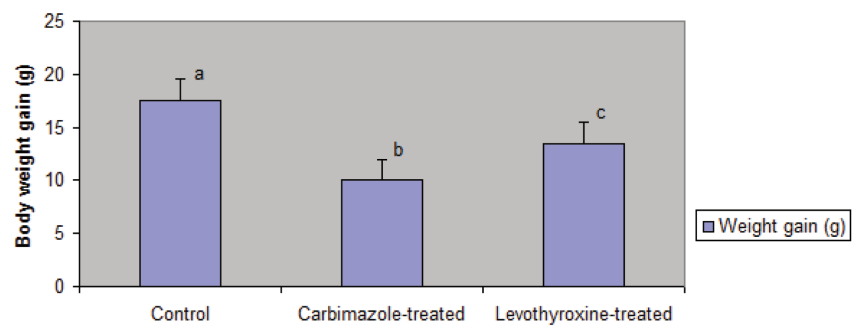

Fig. 1: Effect of thyroid dysfunction on body weight gain. a, b, c - significantly different at $p<0.05$

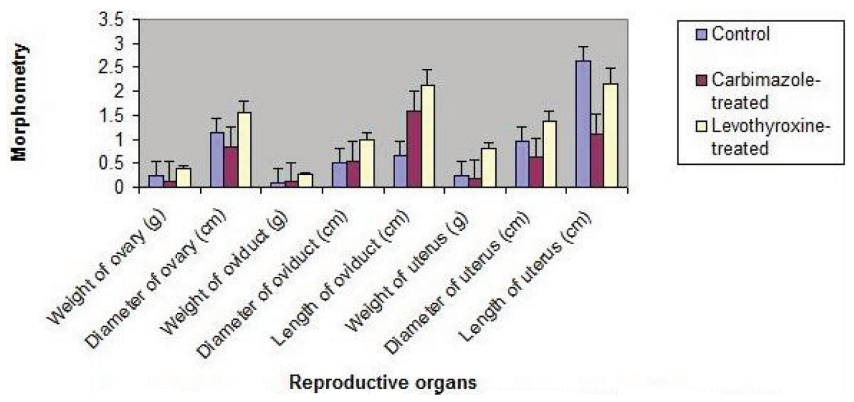

Fig. 2: Effect of thyroid dysfunction on reproductive organ morphometry.

Plasma FSH was similar across all groups. However, LH and oestradiol levels were significantly lower in hypothyroidism and hyperthyroidism in comparison with the control. Hypothyroidism and hyperthyroidism led to significant rise and fall in plasma progesterone, respectively [Fig. 3]. Figure 4 shows the histograph of female reproductive organs.

\section{DISCUSSION}

Thyroid hormones are pivotal to human development, survival and reproductive fecundity. Optimal levels of the thyroid hormones are necessary for normal reproductive development and function. Pathologies associated with

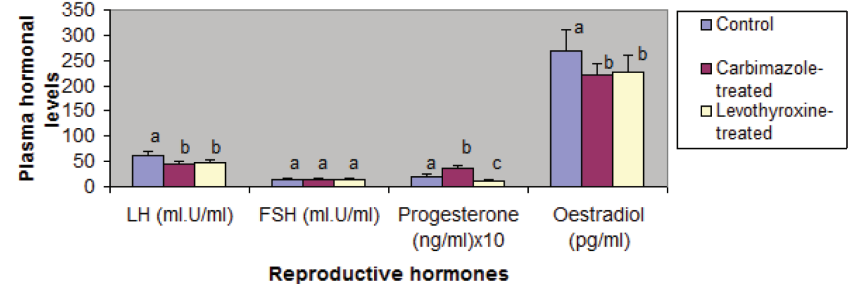

Fig. 3: Effect of thyroid dysfunction on female reproductive hormones. a, b, c - significantly different at $p<0.05$

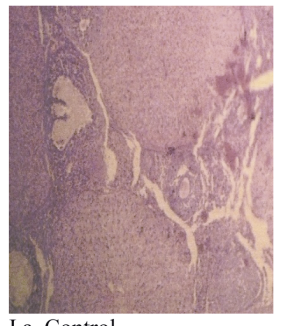

I a. Control

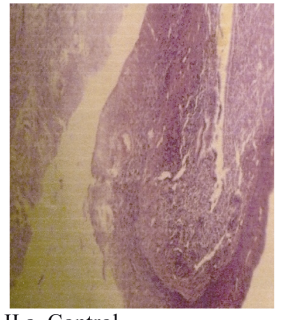

II a. Control

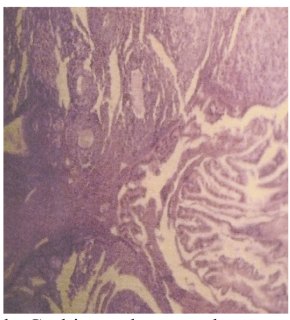

b. Carbimazole-treated

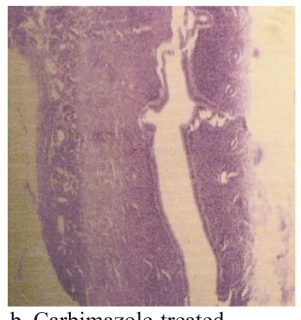

b. Carbimazole-treated

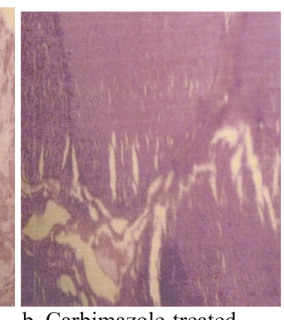

b. Carbimazole-treated

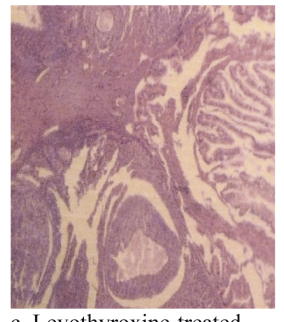

c. Levothyroxine-treated

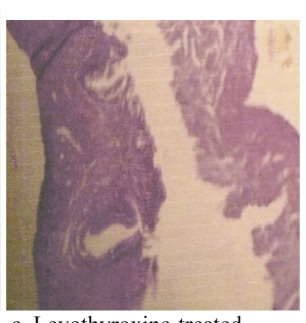

c. Levothyroxine-treated

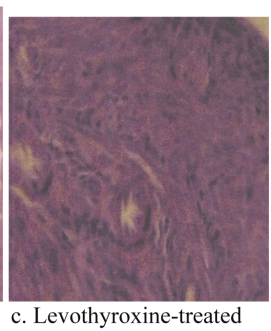

Fig. 4: Histograph showing the effect of thyroid dysfunction in the ovary (I), oviduct (II) and uterus (III).

hypothyroidism and hyperthyroidism thus impair reproductive function. Various studies have documented the effects of altered thyroid states on reproduction. However, none has reported the effect of hypothyroidism and hyperthyroidism on female reproductive hormones and reproductive organs morphometry and histology. To the best of our knowledge and at the time this study was reported, it is the first to document the role of hypothalamic-pituitaryovarian axis and reproductive organs morphometry and histology in thyroid dysfunction-induced impairment of reproductive function.

Although observations from this study showed that altered thyroid states did not influence reproductive organ morphometry, they caused significant reduction in body weight gain. Euthyroid state is required for optimal body 
growth and development. The reduction in body weight gain seen in hyperthyroidism in the present study could be due to increased metabolism and lipolysis induced by excess thyroid hormone via increase in mitochondrial number and activity and increased $\mathrm{Na}^{+}-\mathrm{K}^{+}$-ATPase (18). The hypothyroidism-led reduction in body weight gain could be as a result of hypothyroidism-induced growth retardation.

Findings from this study also revealed that experimental altered thyroid states in animals led to reduced serum levels of LH and oestradiol. This is in contrast with human findings that reported hyperthyroid state-induced increased levels of LH and oestradiol (19-21). However, our findings are consistent with previous laboratory studies $(22,23)$. Though there were no changes in the FSH levels in the hyperthyroid and hypothyroid animals, their low LH levels might account for the low oestradiol level.

Histological findings of this study also showed that thyroid dysfunction altered the cytoarchitecture of female reproductive organs. This seems to be the first study to document the histomorphologic state of female reproductive organs in altered thyroid states. It is a known fact that oestradiol is responsible for the proliferation and growth of specific cells in the body that are responsible for the development of most secondary sexual characteristics of the female (18). The altered cytoarchitecture observed in the study is also associated with low oestradiol level.

Although there are conflicting reports on the effect of altered thyroid states on female reproduction in human and laboratory animals and the mechanism of hypothyroid, and although hyperthyroid-induced impairment of female reproduction is yet to be fully understood, this study suggests that impaired reproductive function seen in altered thyroid states is due to poor weight gain, low LH and oestradiol levels, and alterations in female organs cytoarchitecture. Early diagnosis and prompt management of hypothyroidism and hyperthyroidism are important to preserve female fertility.

\section{REFERENCES}

1. Gaware VM, Parjane SK, Merekar AN, Pattan SR, Dighe NS, Kuchekar BS et al. Female infertility and its treatment by alternative medicine: a review. J Chem Pharm Res 2009; 1: 148-62.

2. Cooper TG, Noonan E, von Eckardstein S, Auger J, Baker HW, Behre $\mathrm{HM}$ et al. World Health Organization reference values for human semen characteristics. Hum Reprod 2010; 16: 231-45.

3. Olooto WE, Ambali AA, Banjo TA. A review of female infertility: important etiological factors and management. J Microbiol Biotech Res 2012; 2: 379-85.
4. Evers JLH, Collins JA. Assessment of efficacy of varicocele repair for male subfertility: a systemic review. Lancet 2003; 361: 1849-52.

5. Ogunniyi SO, Makinde OO, Dare FO. Abortion-related deaths in IleIfe, Nigeria: a 12-year review. Afr J Med Med Sci 1990; 19: 271-4.

6. Esimai OA, Orji EO, Lasisi AR. Male contribution to infertility in IleIfe, Nigeria. Niger J Med 2002; 11: 70-2.

7. Rahman D, Fatima P, Banu J. Thyroid disorders in female subfertility. JCMCTA 2008; 19: 46-50.

8. Burney RO, Schust DJ, Yao MWM. Infertility. In: Berek JS, ed. Berek and Novak's Gynaecology. $14^{\text {th }}$ ed. Philadelphia: Lippincott Williams \& Wilkins; 2007: 1185-1275.

9. Krassas GE, Pontikides N, Kaltsas TH, Papadopoulon PH, Paun KN. Disturbances of menstruation in hypothyroidism. Clin Endocrinol 1999; 50: $655-9$.

10. Ansell JE. The blood in the hypothyroidism. In: Bravermann L, Utiger $\mathrm{R}$, eds. Werner and Ingbar's the thyroid: a fundamental and clinical text. $7^{\text {th }}$ ed. Philadelphia: Lippincott-Raven; 1996: 821-5.

11. Goldsmith RE, Sturgis SH, Lerman J, Standburg JB. The menstrual pattern in thyroid disease. J Clin Endocrinol Metab 1952; 12: 846-55.

12. Ajayi AF, Akhigbe RE. Implication of altered thyroid state on liver function. Thyroid Res Pract 2012; 9: 84-7.

13. Council of Europe. European convention for the protection of vertebrate animals used for experimental and other scientific purposes. European Treaty Series, no. 123. Strasbourg: Council of Europe; 2005.

14. Akhigbe RE, Olatunji LA, Soladoye AO, Oyeyipo IP. Effect of angiotensin 1-converting enzyme inhibitor, captopril, on body weight, and food and water consumption in oral contraceptive-treated rats. Am J Biochem Mol Biol 2011; 1: 95-100.

15. Ajayi AF, Akhigbe RE. Antifertility activity of Cryptolepis sanguinolenta leaf ethanolic extract in male rats. J Hum Reprod Sci 2012; 5: 437.

16. Ajayi AF, Akhigbe RE, Iyiola TO, Adewumi OM, Olaleye SB. Gastric secretagogue action of Cryptolepis sanguinolenta in the perfused stomach of anesthetized rats. Int J Med Biomed Res 2012; 1: 62-7.

17. Ige SF, Akhigbe RE, Olaleye SB, Adeyemi JW. Gastroprotective potentials of the methanolic extract of Garcinia kola in rats. Int J Med Biomed Res 2012; 1: 172-8.

18. Guyton AC, Hall JE. Endocrinology and reproduction. In: Hall JE, Guyton AC. Guyton and Hall Textbook of Medical Physiology. 11 $1^{\text {th }}$ ed. Philadelphia: Elsevier Saunders; 2008: 903-1052.

19. Krassas GE. Thyroid disease and female reproduction. Fertil Steril 2000; 74: 1063-70.

20. Akande EO. The effect of oestrogen on plasma levels of luteinizing hormone in euthyroid and thyrotoxic postmenopausal women. J Obstet Gynaecol Br Commonw 1974; 81: 795-803.

21. Zähringer S, Tomova A, von Werder K, Brabant G, Kumanov P, Schopohl J. The influence of hyperthyroidism on the hypothalamicpituitary-gonadal axis. Exp Clin Endocrinol Diabetes 2000; 108: 282 9 .

22. Longcope C. The male and female reproductive systems in hypothyroidism. In: Braverman LE, Utiger RD, eds. Werner and Ingbar's the thyroid: a fundamental and clinical text. $8^{\text {th }}$ ed. Philadelphia: Lippincott Williams \& Wilkins; 2000: 824-828.

23. Howland BE, Ibrahim EA. Hyperthyroidism and gonadotropin secretion in male and female rats. Experientia 1973; 29: 398-9. 